\title{
PENGADAAN TEMPAT SAMPAH
}

(KELURAHAN BONTOTANGNGA KEC.TAMALATEA)

NAMA : ANNISA HASAN

NIM : 9173490210030

EMAIL : annisahasan3011@gmail.com

1. Bentuk Kegiatan

- Pembuatan Tempat Sampah

2. Lokasi

- Kantor Kelurahan Bontotangnga

- Kantor Kecamatan Tamalatea

- Koramil

- Posko KKLP Kel.Bontotangnga

3. Hari/Tanggal Dan Waktu

- Sabtu, 03 Oktober 2020 Pukul 14.00 WITA

4. Peserta Yang Dilibatkan

- Mahasiswa KKLP YAPTI JENEPONTO

5. Alasan Yang Diadakannya

- Kami melihat beberapa instansi memiliki tempat sampah yang kurang layak bahkan tidak memiliki tempat sampah sehingga kami memilih untuk membuat program kerja ini.

6. Tujuan Dan Manfaat

- Kami mengadakan Program Kerja ini agar kebersihan tetap terjaga serta membuang sampah pada tempatmya

7. Deskripsi Kegiatan

- Proses pembuatan tempat sampah ini di lakukan oleh seluruh mahasiswa KKLP. Kegiatan ini dilaksanakan selama beberapa hari, pembuatan tempat sampah dilakukan sebagai upaya 
menjaga kebersihan pekarangan di setiap instansi yang mana ,selama ini banyak sampah berserakan di sebabkan tidak tersedianya tempat sampah. 